\title{
Cellular injury evidenced by impedance technology and infrared microspectroscopy
}

\author{
K. le Roux ${ }^{\mathrm{a}}$, L.C. Prinsloo ${ }^{\mathrm{b}}$ and D. Meyer $^{\mathrm{a} 1}$ \\ ${ }^{a}$ Department of Biochemistry, University of Pretoria, Pretoria, 0002, South Africa \\ b Department of Physics, University of Pretoria, Pretoria, 0002, South Africa
}

\section{Key words:}

FTIR, RT-CES, cytostatic, cytotoxic, cancer

\section{Highlights:}

- FTIR detects different types of cell injury in a manner comparable to RT-CES.

- Spectral differences distinguish cytostasis from cytotoxicity.

- FTIR microspectroscopy detects the reversibility of cytostasis.

\footnotetext{
${ }^{1}$ Corresponding author: Prof. D. Meyer, telephone number: +2712 420 3200, email: debra.meyer@up.ac.za
} 


\section{Abstract}

Fourier Transform Infrared (FTIR) spectroscopy is finding increasing biological application, for example in the analysis of diseased tissues and cells, cell cycle studies and investigating the mechanisms of action of anticancer drugs. Cancer treatment studies routinely define the types of cell-drug responses as either total cell destruction by the drug (all cells die), moderate damage (cell deterioration where some cells survive) or reversible cell cycle arrest (cytostasis). In this study the loss of viability and related chemical stress experienced by cells treated with the medicinal plant, Plectranthus ciliatus, was investigated using real time cell electronic sensing (RT-CES) technology and FTIR microspectroscopy. The use of plants as medicines is well established and ethnobotany has proven that crude extracts can serve as treatments against various ailments. The aim of this study was to determine whether FTIR microspectroscopy would successfully distinguish between different types of cellular injury induced by a potentially anticancerous plant extract. Cervical adenocarcinoma (HeLa) cells were treated with a crude extract of Plectranthus ciliatus and cells monitored using RT-CES to characterize the type of cellular responses induced. Cell populations were then investigated using FTIR microspectroscopy and statistically analysed using One-way Analysis of Variance (ANOVA) and Principal Component Analysis (PCA). The plant extract and a cancer drug control (actinomycin D) induced concentration dependent cellular responses ranging from nontoxic, cytostatic or cytotoxic. Thirteen spectral peaks $\left(915 \mathrm{~cm}^{-1}\right.$, $933 \mathrm{~cm}^{-1}, 989 \mathrm{~cm}^{-1}, 1192 \mathrm{~cm}^{-1}, 1369 \mathrm{~cm}^{-1}, 1437 \mathrm{~cm}^{-1}, 1450 \mathrm{~cm}^{-1}, 1546 \mathrm{~cm}^{-1}, 1634 \mathrm{~cm}^{-1}, 1679$ $\mathrm{cm}^{-1} 1772 \mathrm{~cm}^{-1}, 2874 \mathrm{~cm}^{-1}$ and $2962 \mathrm{~cm}^{-1}$ ) associated with cytotoxicity were significantly (p value $<0.05$, one way ANOVA, Tukey test, Bonferroni) altered, while two of the bands were also indicative of early stress related responses. In PCA, poor separation between nontoxic and cytostatic responses was evident while clear separation was linked to cytotoxicity. RTCES detected morphological changes as indicators of cell injury and could distinguish between viable, cytostatic and cytotoxic responses. FTIR microspectroscopy confirmed that cytostatic cells were viable and could still recover while also describing early cellular stress related responses on a molecular level. 


\section{Graphical abstract}

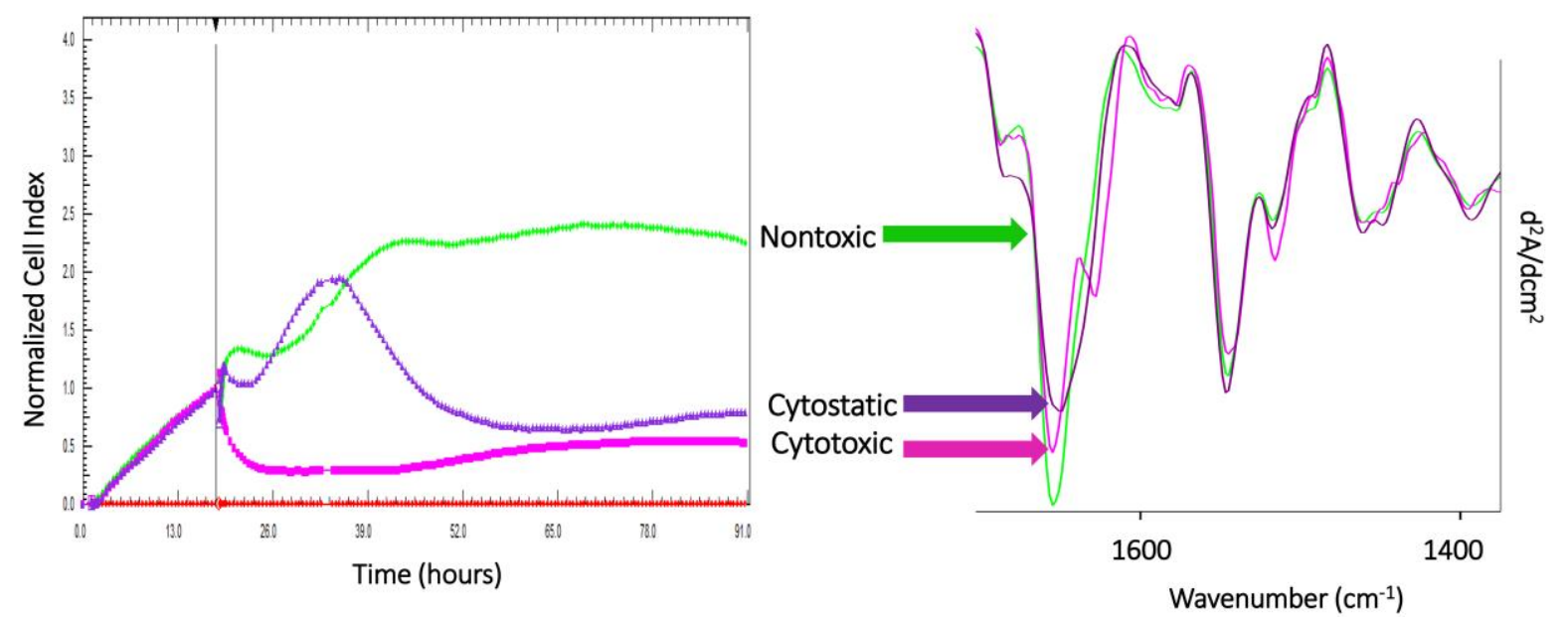




\section{Introduction}

Fourier Transform Infrared spectroscopy is a label free, non-destructive, high throughput method which is growing in popularity as the applications increase. The applications of the technique include structure elucidation of compounds [1] and peptides [2,3], identification of different bacterial strains [4,5] and antimicrobial compounds affecting bacterial viability [6], the discrimination of diseased and healthy tissues or cells [7-9], cell cycle analysis [10], the effects of known toxins on cells [11] and the identification of molecular targets of natural and synthetic anticancer drugs [12-15].

Anticancer drugs under development are generally tested in vitro to determine whether they can be classified as non-toxic (no or limited cell death caused), cytostatic (arrest of cell proliferation but the cells are essentially still alive) or cytotoxic (considerable cell death induced by the treatment). Cytostatic responses are usually employed to stop uncontrolled tumour growth while cytotoxic responses lead to cell death caused by apoptosis, necrosis or cell lysis [16]. Cytostatic and cytotoxic behaviour plays an important role in the progression of a drug into preclinical and clinical studies. Cytostatic drugs have been found to be metastases preventative and increase the survival rates of patients by delaying the time to disease progression [17]. Cytotoxic drugs, on the other hand, are less selective and the induced cell death could be more detrimental to the patient in terms of side effects. Rixe and Fojo (2007) found that a drug elicited either cytostatic or cytotoxic cellular responses depending on its active concentration [17].

Classifications of cytostasis / cytotoxicity are usually decided following spectrophotometric assessment of cell viability in the presence of the drug and a labelling agent, but the use of spectroscopy in the absence of labels is gaining momentum. Conventionally, biochemical labels such as trypan blue, tetrazolium salts and fluorochromes are used to measure a single parameter such as; membrane integrity, enzymatic reactions and intra- or extracellular markers. The major disadvantage of labels is that the experiment becomes an end point analysis measuring only one or a few parameters at a particular time point after which the cells are destroyed. Biochemical labels are also very expensive and can sometimes crossreact with other molecules. Accordingly, new label free methodologies that are less time- 
consuming and more comprehensive in evaluating multiple cellular components should be developed.

One of the popular label free assays currently in use is RT-CES. The principle of the instrument is based on the growth of adherent cells on gold electrodes. Impedance changes associated with the cells behaviour is measured continuously. When cells initially attach to the electrodes the impedance (electrical resistance) increases, causing an increase in the unit less Cell Index (CI). The CI will increase as the resistance increases, which are due to the cells proliferating or spreading out within the culture well. When a toxin is added to the wells, the cellular response can be measured continuously. Thus, any change in cell size and shape is monitored by changes within the CI. Generally a decrease in CI values could be due to cell volume decreasing, cells rounding up during the activation of cell death or the detachment of cells which leads to a decrease in resistance measured by the electrodes [18]. This technique successfully characterized the type of cellular responses of importance in our research group $[19,20]$ as well as others $[16,21-23]$.

In a previous study, we found that Raman micro-spectroscopy could be used to pre-screen a plant extract for its anticancer activity against the proliferation of leukemic U-937 cells [24]. Since FTIR spectroscopy is complementary to Raman spectroscopy and Raman spectroscopy only interrogates one cell at a time, we set out to determine whether FTIR could distinguish viable from cytostatic and cytotoxic responses in a given cell population following exposure to a cell death inducer. Many publications focus on the cytotoxic drugs and plant extracts or compounds affecting FTIR spectra of treated cells [11,13,14,25,26] while little research had been done on cytostatic responses [15].

In the evaluation of FTIR spectroscopy as a tool for the screening of anticancer drug responses, a cell death inducer is required. In this case a South African traditional medicinal plant was selected. Medicinal plants have long been studied for their effectiveness in treating cancer. Crude extracts of medicinal plants are more potent cytotoxins because of the synergy of the many phytochemicals found in the mixture [24]. The cell death inducer in this investigation was a leaves extract of Plectranthus ciliatus. In traditional medicine, plants from this genus are used to treat ailments of the digestive tract, respiratory system, nervous system, inflammation, infections, pain and different types of cancers [27]. The plant's 
anticancer activity was previously demonstrated by our group [28]. The aim of this study was to determine whether FTIR microspectroscopy could successfully distinguish between different types of cellular injury induced by a potentially anticancerous plant extract.

\section{Methods}

\subsection{Plant material and extraction}

Plectranthus ciliatus leaves were harvested in the Manie van der Schijff botanical garden, Pretoria, South Africa. The leaves were authenticated and a voucher specimen deposited in the Schweickerdt Herbarium, Pretoria, South Africa. The crude extract of the leaves was prepared and kindly donated by Dr. T. P. Kapewangolo, Department of Biochemistry, University of Pretoria. The plant extraction procedure was done as previously described [20]. The crude extract was stored at $4^{\circ} \mathrm{C}$ until use. Stock solutions were freshly prepared before each experiment by dissolving the plant extract in cell culture tested dimethyl sulfoxide (DMSO) (Sigma, Germany).

\subsection{Cell culture}

Human cervix adenocarcinoma (HeLa) cells were purchased from Highveld Biological (Pty) Ltd. (Johannesburg, South Africa) and grown in standard culture flasks in a humidified incubator at $37^{\circ} \mathrm{C}$ and $5 \% \mathrm{CO}_{2}$. The growth media was Minimum Essential Medium (MEM), supplemented with 5\% heat-inactivated foetal bovine serum (FBS) (Hyclone, Separations, Johannesburg, South Africa) and antimicrobial cocktail (100 U/mL penicillin, $100 \mu \mathrm{g} / \mathrm{mL}$ streptomycin and $250 \mu \mathrm{g} / \mathrm{L}$ fungizone) (Hyclone, Separations, Johannesburg, South Africa). The cells were maintained by sub-culturing the cells when $80-90 \%$ confluence was reached.

\subsection{Real time cell analysis of plant extract treated HeLa cells}

An RT-CES device (Roche Diagnostics, Mannheim, Germany) in a humidified incubator was used to observe the proliferation of the cells in the absence and presence of the selected plant extract. Cell titrations (5 $000-60000$ cells / well) were done to determine the optimal cell number for the experiments. The specific concentration $\left(1 \times 10^{5}\right.$ cells/well $)$ where the optimal exponential growth curve was found, was used for further studies as recommended by Fonteh et al. (2011) [19]. Three different concentrations ( $0.5 \mathrm{x}$ cytotoxic concentration of 
a treatment affecting $50 \%$ of the cell population tested $\left(\mathrm{CC}_{50}\right), \mathrm{CC}_{50}$ and $2 \times \mathrm{CC}_{50}-$ determined by the tetrazolium dye XTT, Table 1) of the treatments were tested alongside the positive control (actinomycin D). The plant extract was dissolved in DMSO (ensure that all components were solubilized) to a stock solution of $20 \mathrm{mg} / \mathrm{mL}$, while actinomycin D was completely dissolved in only sterile distilled water to a stock solution of $1 \mathrm{mg} / \mathrm{mL}$. Further dilutions were made in complete media before the assays were conducted. Controls; a background (media only, no cells), untreated cells (cells and media) and a vehicle control (DMSO at $0.09 \%$ ) were included every time. Electronic impedance increases as cells attach to the electrodes and is known as the Cell Index (CI). The cells were incubated in a humidified incubator for approximately 18 hours where the unit less $\mathrm{CI} \approx 1$, after which the treatments were added to the E-plates, final volume $250 \mu \mathrm{L}$. Cells were monitored for a total of 90 hours. Data sets were normalized at the point where cells were treated. The Cell Index was normalized using a build in function of the Roche xCelligence Software 1.2.1. The normalized CI is calculated automatically for each well as the CI at a given time point, divided by the $\mathrm{CI}$ at the normalized time point (Normalized $\mathrm{CI}_{\text {time }}=\mathrm{CI}_{\text {time }} / \mathrm{CI}_{\text {normalized_time }}$ ). Therefore, the Normalized Cell Index for all wells must be equal one (1) at the normalization time point. Cells exhibited varying response patterns represented by CI changes that either indicated the cells as growing (increasing CI), dying (decreasing CI) or experiencing proliferation arrest (unchanging CI). Three independent experiments were conducted.

Table 1. Concentrations of the cell death inducers used in the RT-CES experiment

\begin{tabular}{|ccc|}
\hline Cytotoxic concentration ratios & Plectranthus ciliatus & Actinomycin D \\
\hline $0.5 \times \mathrm{CC}_{50}$ & $4.5 \mu \mathrm{g} / \mathrm{mL}$ & $0.01 \mu \mathrm{g} / \mathrm{mL}$ \\
\hline $\mathrm{CC}_{50}{ }^{(\mathrm{a})}$ & $9 \mu \mathrm{g} / \mathrm{mL}$ & $0.02 \mu \mathrm{g} / \mathrm{mL}$ \\
\hline $2 \times \mathrm{CC}_{50}$ & $18 \mu \mathrm{g} / \mathrm{mL}$ & $0.04 \mu \mathrm{g} / \mathrm{mL}$ \\
\hline
\end{tabular}

(a) Determined by XTT

Cytotoxic concentrations of the treatment affecting $50 \%$ of the cell population tested $\left(\mathrm{CC}_{50}\right)$ based on RT-CES data were calculated using Roche xCelligence Software 1.2.1. The $\mathrm{CC}_{50}$ values were expressed as the mean of three independent assays and the variability between repeats as standard error of the mean (SEM). RT-CES graphs were used to determine whether the responses to treatment were cytotoxic or cytostatic by using guidelines published by Kustermann et al. (2013) [16]. The line at CI = 1 divided the graphs into viable / 
proliferating cells (CI > 1) and nonproliferating / dying cells $(\mathrm{CI}<1)$ from each other (Fig. 1). Three typical graphs were described in Kustermann et al. (2013), where the response of cells in the absence or presence of treatments were described. Where the CI was more than 1 , the cells were viable / proliferating indicative of cells under no stress. Where the CI $<1$ the cells experienced toxicity. Lastly, when the growth curve moved from $\mathrm{CI}>1$ to a $\mathrm{CI}<1$ during the observation time the cells could be defined as experiencing cytostatic responses [16].

For the FTIR investigation, methods published by Zelig et al. (2009) and Machana et al. (2012) were used as a guideline during the optimization of the experiments [14,29]. Exponentially growing HeLa cells were seeded ( 1 x $10^{5}$ cells) and incubated in 12-well plates. After 24 hours incubation, the cells were exposed to two different concentrations $\left(\mathrm{CC}_{50}\right.$ and $\left.2 \times \mathrm{CC}_{50}\right)$ of the plant extract and actinomycin D respectively (Table 1). Vehicle (0.09\% DMSO) and negative control (untreated) cells were included in the analyses. Cells were incubated for 72 hours, after which all the cells were collected from each well. Cells were centrifuged for 10 minutes, the supernatant discarded and the pellets washed twice with $1 \mathrm{~mL}$ phosphate buffered saline (PBS) to remove all traces of the culture media. The cells were incubated at room temperature in $1 \mathrm{~mL} 10 \%$ formalin (in PBS) for 10 minutes to fixate the cells. The cells were centrifuged for five minutes and the supernatant discarded. The cells were washed twice with $1 \mathrm{~mL}$ of sterile distilled water and centrifuged for three minutes to remove all traces of formalin and PBS, which could influence the spectra. The supernatant was removed and the cells suspended in $10 \mu \mathrm{L}$ sterile distilled water. The cell suspensions (3 $\mu \mathrm{L}$ ) were dried in the biosafety flow hood for one hour on sterile $\mathrm{CaF}_{2}$ discs (Crystran, $\mathrm{UK}$ ).

The FTIR spectra were acquired using a Bruker V70x spectrometer equipped with a Hyperion 15x IR objective (Bruker, Germany). Using a liquid nitrogen cooled detector attached to the microscope, ten areas were analysed containing a lawn of cells (approximately 400 cells / area). Spectra in the range of $850-4000 \mathrm{~cm}^{-1}$ were recorded. Data were collected in transmission mode and spectra $\left(4 \mathrm{~cm}^{-1}\right.$ spectral resolution, $2 \mathrm{~cm}^{-1}$ intervals, co-added for 100 scans) recorded using Bruker OPUS software. Three independent experiments were conducted. All the spectra were pre-processed using OPUS 7 software. Atmospheric contributions (water vapour and $\mathrm{CO}_{2}$ ) were subtracted and the spectra vector normalized. 
Baseline correction was done using the rubber band function. Second derivatives were calculated (17 smoothing points using the built in Savitzky-Golay algorithm to improve the signal-to-noise ratio) and used for interpretation and statistical analysis [29]. Second derivatives were analysed to assign accurately and visually maximize differences [14,29].

Average spectra of the treatment groups were constructed and One-way Analysis of Variance (ANOVA) calculated. A p 0.05 was considered significant. Bonferroni multiple comparison tests in conjunction with Tukey post-hoc testing were done in SPSS 20 to determine which variances were significant. An unsupervised method, principal component analysis (PCA) was used to identify trends in the spectra. The data sets were reduced by five principal components and mean centred. The PCA plot was constructed in OPUS 7 while Principal Component (PC) variances were calculated in SPSS 20.

\section{Results and discussion}

In the current study, the effects of a crude extract (Plectranthus ciliatus leaves) against HeLa cells proliferation were investigated using FTIR microspectroscopy to distinguish between cytostatic and cytotoxic cellular responses. RT-CES, a well-established technique used for making these distinctions (among others) served as a reference point for the FTIR spectroscopic data.

\subsection{Real Time Cell Electronic Sensing of treated HeLa cells}

Distinctions between cytotoxic and cytostatic responses were determined using Kustermann and colleagues (2013) manuscript as a guideline [16] who found the area under the curve to be indicative of the type of cellular response. The analysis model created by Kustermann et al. [16] was constructed following on assessment of the behaviour of T3T fibroblast cells when exposed to three different compounds; Indocine (anti-inflammatory drug, nontoxic), Vandetanib (tyrosine kinase inhibitor, cytotoxic) and Dasatinib (kinase inhibitor, cytostatic affecting cell cycle). The analysis model was then tested by that same research group with 40 known compounds inducing well documented cellular responses in vivo and was confirmed to have good correlation with known records. 
Graphs were analysed and indicated in Fig. 2. The line at $\mathrm{CI}=1$ divided the graphs into viable / proliferating cells $(\mathrm{CI}>1)$ and nonproliferating / dying cells $(\mathrm{CI}<1)$ from each other (Fig. 1). Three typical graphs were described in Kustermann et al. (2013), where the response of cells in the absence or presence of treatments were described. Where the CI was more than 1 , the cells were viable / proliferating indicative of cells under no stress. Where the $\mathrm{CI}<1$ the cells experienced toxicity. Lastly, when the growth curve moved from CI $>1$ to a $\mathrm{CI}<1$ during the observation time the cells could be defined as experiencing cytostatic responses [16].
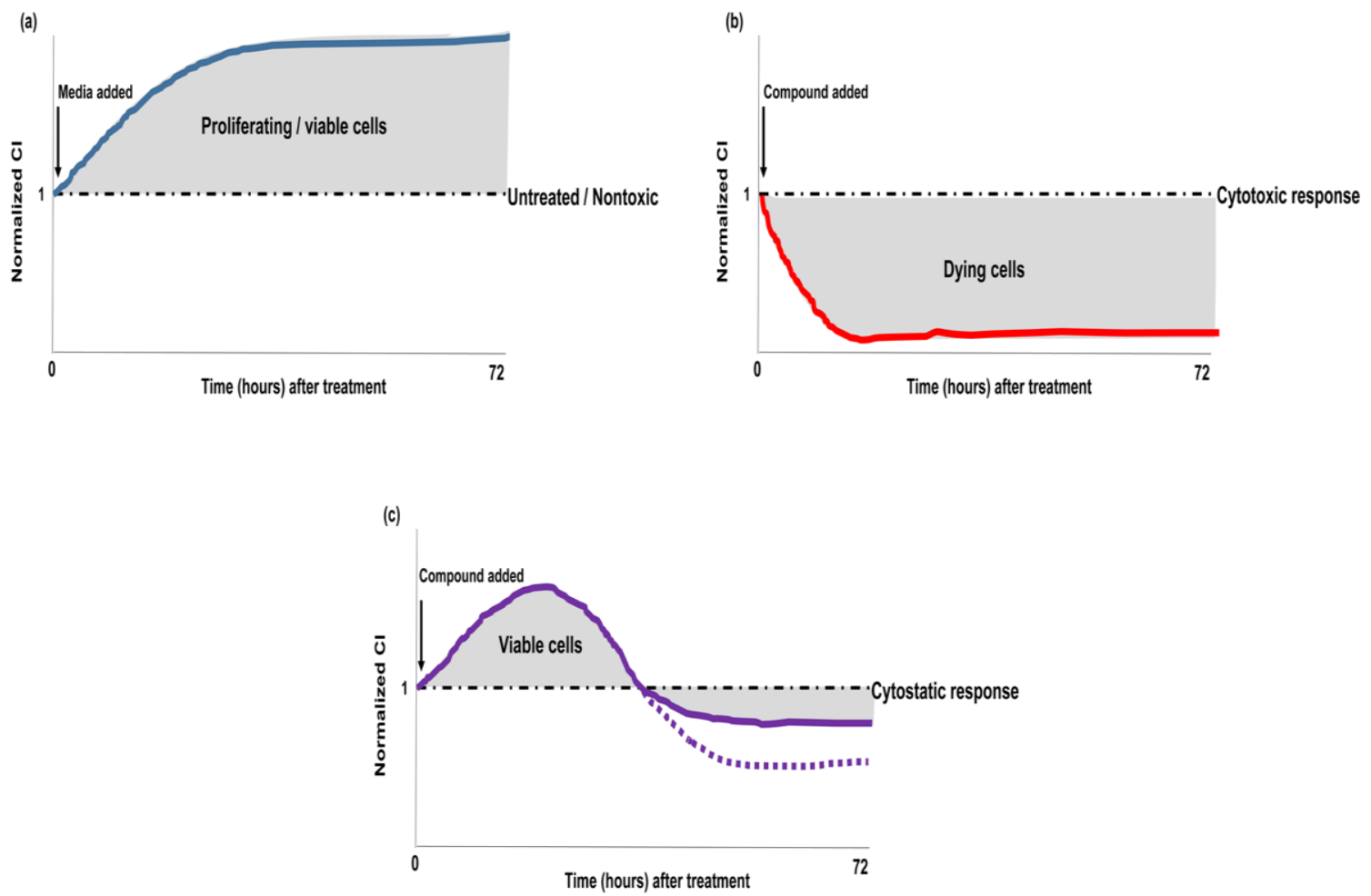

Fig. 1. Representative graphs of cellular responses monitored with RT-CES, where the data is normalized from compound addition until the experiment is stopped approximately 72 hours after the addition of the treatment. Data is normalized to $\mathrm{CI}=1$ and a line at 1 is indicated in each of the graphs. Untreated or vehicle treated cells where cells grow normally / as expected (CI > 1), the graph appears as shown in (a) where nontoxic responses has similar graph trends as compared to untreated and treated cells, (b) is a representation of a cytotoxic compound where the CI $<1$ and finally (c) represents a cytostatic response where the cells firstly has a $\mathrm{CI}>1$ and as time progress has a $\mathrm{CI}<1$ in the observation time. 
Preliminary screening of the plant extract using XTT gave a $\mathrm{CC}_{50}$ value of $9 \mu \mathrm{g} / \mathrm{mL}$ while actinomycin D (positive control) produced a $\mathrm{CC}_{50}$ value of $0.02 \mu \mathrm{g} / \mathrm{mL}$ (Table 1). Three concentrations based on these $\mathrm{CC}_{50}$ values were investigated using the RT-CES system. The RT-CES system established the crude extract and actinomycin D as having $\mathrm{CC}_{50}$ values of 15 $\pm 1.8 \mu \mathrm{g} / \mathrm{mL}$ and $0.015 \pm 0.003 \mu \mathrm{g} / \mathrm{mL}$ respectively (Fig. 2). The difference in $\mathrm{CC}_{50}$ determined by the two approaches is a testament to the improved sensitivity of RT-CES compared to conventional viability assays.

RT-CES graphs were compared to the graphs in Fig. 1 that distinguished the type of cellular responses observed (Fig. 2 and Table 2). Actinomycin D was dissolved in sterile distilled water while the plant extract was dissolved in DMSO to ensure that the mixture of components dissolved. Untreated cells were thus used as the control cells for actinomycin D treated cells while DMSO treated cells were used for plant extract treated cells. Vehicle (DMSO) treated HeLa cells had a very similar graph and proliferation profile as untreated cells and therefore nontoxic. When HeLa cells were treated with the crude extract at a concentration of $18 \mu \mathrm{g} / \mathrm{mL}\left(2 \times \mathrm{CC}_{50}\right.$ determined by XTT), there was a sudden and severe cell response within the first 10 hours after the addition of the treatment. The cell response observed included the size of the cells decreasing as well as cell detachment that led to a CI below 0.5 that remained constant (Fig. 2a). Cells treated with $18 \mu \mathrm{g} / \mathrm{mL}$ crude extract had a typical graph associated with cytotoxicity. Treatment of the cells with lower concentrations of the crude extract of Plectranthus ciliatus $(4.5 \mu \mathrm{g} / \mathrm{mL}$ and $9 \mu \mathrm{g} / \mathrm{mL})$ caused a minor decrease in CI values with similar growth trends as untreated cells (where the CI values remain similar to the CI values of treated cells, then the treatment was nontoxic). The cells treated with $9 \mu \mathrm{g} / \mathrm{mL}$ (the $\mathrm{CC}_{50}$ ) showed a decrease of $20 \%$ in viability when comparing the CI values of DMSO treated cells. The areas were also not meaningfully different from the untreated- and DMSO cells and thus the cellular response small. The plant extract elicited nontoxic and cytotoxic cellular responses which depended upon the concentrations of the plant extract. Cytotoxicity of the extract can be traced back to the phytochemicals (including diterpenes) documented for this plant in the literature. Diterpenes isolated from the Plectranthus genus had been identified as having anti- neoplastic activity [30]. One of the speculated compounds which might have caused inhibition of cell proliferation as well as detachment of cells is rosmarinic acid which is found only in the subfamily of Nepetoideae of which Plectranthus ciliatus is a member [31,32]. 
Actinomycin D treated HeLa cells exhibited an entirely different cellular response when compared to the crude extract treated cells (Fig. 2b). When the cells were treated at higher concentrations of actinomycin D, the CI decreased more dramatically compared to the lower concentrations. The RT-CES graphs indicated that lower concentrations of actinomycin D induced minor changes and were, therefore, nontoxic. After the cells were treated with 0.04 $\mu \mathrm{g} / \mathrm{mL}$ actinomycin $\mathrm{D}\left(2 \times \mathrm{CC}_{50}\right)$, the drug significantly changed the cellular response. In this case actinomycin D elicited a cytostatic cellular response. Sawicki \& Godman (1971) observed that the induction of apoptosis in HeLa cells were evident at concentrations between $1-10 \mu \mathrm{g} / \mathrm{mL}$ actinomycin $\mathrm{D}$, while cell deterioration was delayed when the cells were treated with lower concentrations $(0.1-0.01 \mu \mathrm{g} / \mathrm{mL})$. During the $\mathrm{S}$ - and G2-phase, actinomycin D is incorporated within DNA causing the cells to have cytostatic characteristics $[33,34]$ as seen here as well. 

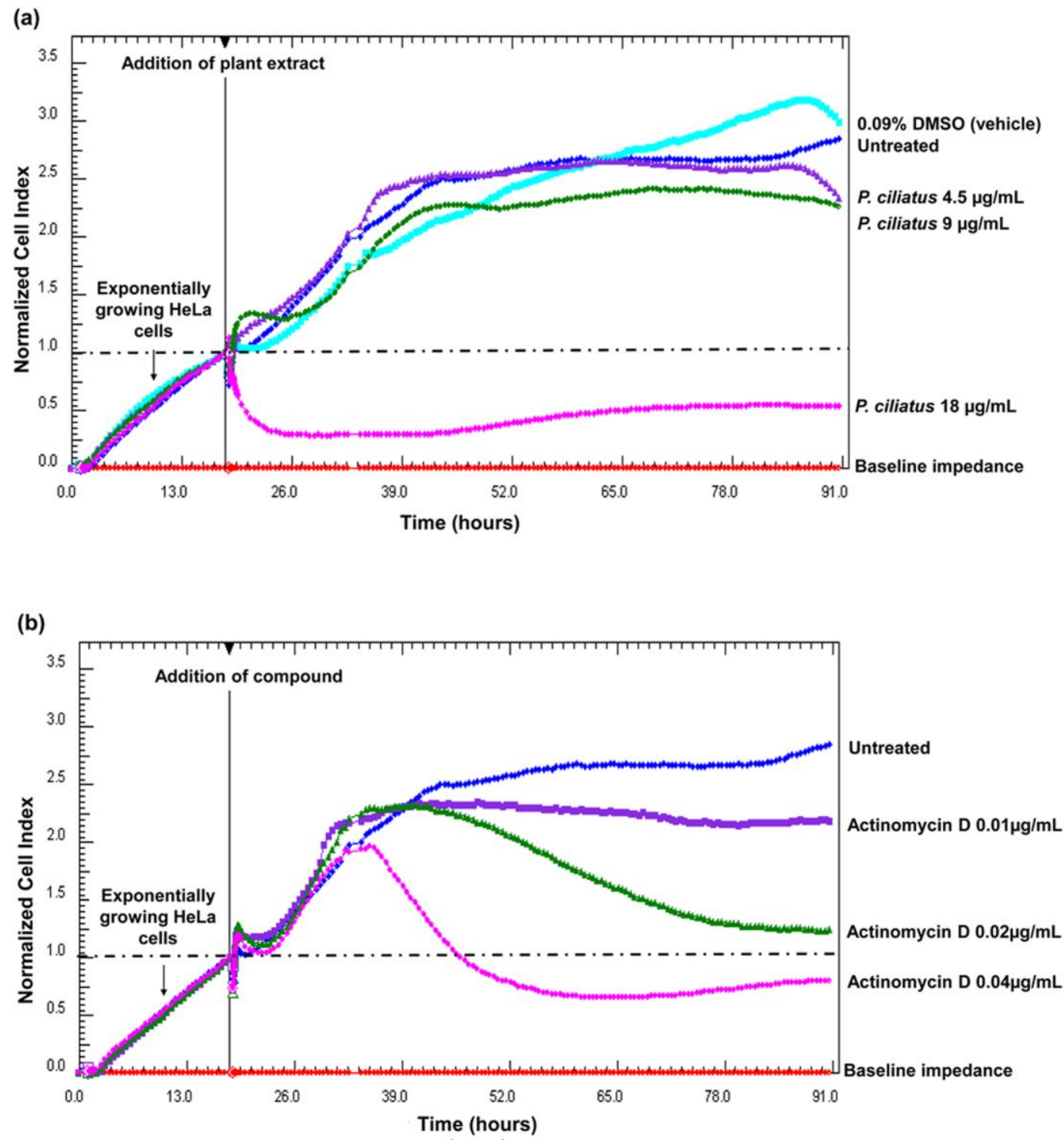

Fig. 2. Representative graphs of the effect on proliferation of (a) Plectranthus ciliatus extract and (b) actinomycin D (cell death inducer) treated HeLa cells using RT-CES. Cells were incubated for approximately 18 hours after which the treatments at three different concentrations of the treatments were performed. In (a), the vehicle (DMSO) and media-only cells show minimal CI changes. The plant extract treated cells were severely affected by $18 \mu \mathrm{g} / \mathrm{mL}$ which led to a sudden decrease in the CI values. In (b) the affects were also more severe as compared to actinomycin D treated cells $(0.04 \mu \mathrm{g} / \mathrm{mL})$. 
Table 2. Summary of the treatments and cellular responses after treatment.

\begin{tabular}{|cc|}
\hline Treatment & Assignment \\
\hline Untreated & - \\
\hline DMSO & Nontoxic \\
\hline Plectranthus ciliatus $4.5 \mu \mathrm{g} / \mathrm{mL}$ & Nontoxic \\
\hline Plectranthus ciliatus $9 \mu \mathrm{g} / \mathrm{mL}$ & Nontoxic \\
\hline Plectranthus ciliatus $18 \mu \mathrm{g} / \mathrm{mL}$ & Cytotoxic \\
\hline Actinomycin D $0.01 \mu \mathrm{g} / \mathrm{mL}$ & Nontoxic \\
\hline Actinomycin D $0.02 \mu \mathrm{g} / \mathrm{mL}$ & Nontoxic \\
\hline Actinomycin D $0.04 \mu \mathrm{g} / \mathrm{mL}$ & Cytostatic \\
\hline
\end{tabular}

\subsection{FTIR spectral analysis of HeLa cells treated with actinomycin D and Plecthrantus}

\section{ciliatus}

RT-CES demonstrated a cytostatic response for actinomycin D $(0.04 \mu \mathrm{g} / \mathrm{mL})$, while the effects of $P$. ciliatus $(18 \mu \mathrm{g} / \mathrm{mL})$ was cytotoxic. The sensitivity of FTIR microspectroscopy was evaluated to assess whether similar observations would be evident. Spectra were recorded for untreated and treated cells in the region of $4000-850 \mathrm{~cm}^{-1}$ (Fig. 3) and exhibited bands originating from lipids, proteins and carbohydrates (Table 3). Increasing signal to noise levels originated when the cells were treated with the crude extract of P. ciliatus. The increase in noise was concentration dependent as can be seen in Fig. 3. The noise was likely due to the crude extract containing numerous compounds causing noise in the region between 1800 and $2000 \mathrm{~cm}^{-1}$. The presence of the noise in the region between 1800 and $2000 \mathrm{~cm}^{-1} \mathrm{did}$ not lead to any spectral shift since shifts were not apparent in the averaged spectra nor the second derivatives (Fig. S1). In Table 3, the mid infrared band assignments common to biological samples were summarized. Major vibrational bands of untreated HeLa cells in the fingerprint region were similar to proliferating HeLa cells investigated previously $[10,35]$. No major spectral differences were observed between vehicle control (0.09\% DMSO) and untreated cells. 


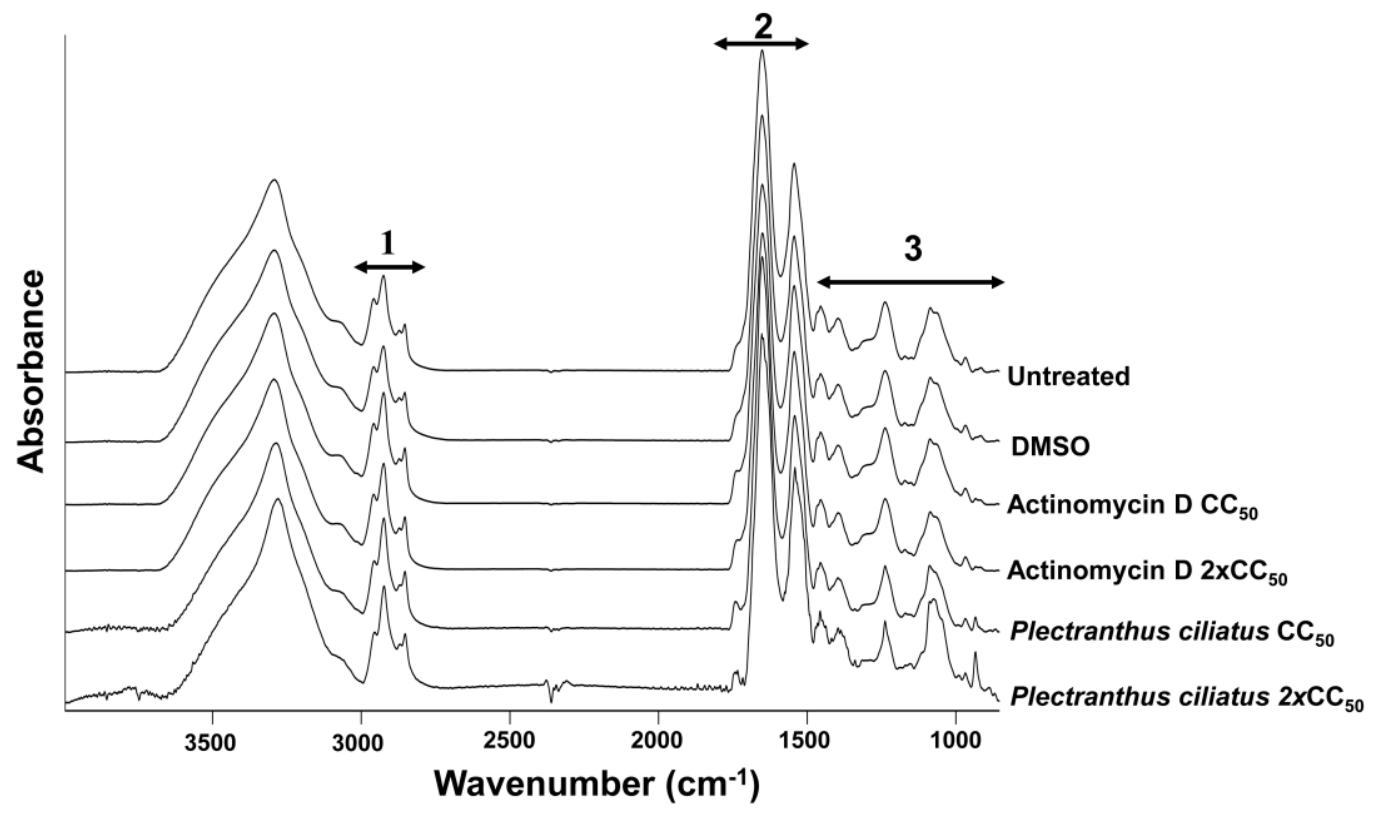

Fig. 3. Average spectra of FTIR spectral features in the regions between $850-4000 \mathrm{~cm}^{-1}$ of untreated and treated HeLa cells. The interaction between HeLa cells and the treatments Plectranthus ciliatus and actinomycin $D$ at two different concentrations. Major vibrations assigned to biological molecules are indicated.

Table 3. Major mid infrared spectral ranges in cells

\begin{tabular}{|c|c|c|}
\hline Region & Spectral range & Assignment \\
\hline 1 & $3000-2800 \mathrm{~cm}^{-1}$ & $\begin{array}{l}\text { Stretching vibrations of } \mathrm{CH}_{2} \text { and } \mathrm{CH}_{3} \text { contained mainly in the lipid acyl } \\
\text { chains and to a lesser extent proteins }[12,36]\end{array}$ \\
\hline 2 & $1800-1300 \mathrm{~cm}^{-1}$ & $\begin{array}{l}\text { Absorptions were due to proteins, the shoulder band around 1738-1745 } \\
\mathrm{cm}^{-1} \text { was assigned to } \mathrm{C}=\mathrm{O} \text { stretching mode of phospholipids. Protein } \\
\text { amide } \mathrm{C}=\mathrm{O} \text { stretching took place around } 1655 \mathrm{~cm}^{-1} \text { (amide I) and the } \\
\text { amide } \mathrm{N}-\mathrm{H} \text { bond (amide II) appears at } 1546 \mathrm{~cm}^{-1} \text {. Bands around 1480- } \\
1300 \mathrm{~cm}^{-1} \text { were caused by amino acids side chains and fatty acids } \\
{[2,12,13]}\end{array}$ \\
\hline 3 & $1300-850 \mathrm{~cm}^{-1}$ & $\begin{array}{l}\text { The absorptions were from carbohydrates and phosphates associated } \\
\text { with nucleic acids. The vibrational bands at } 1238 \mathrm{~cm}^{-1} \text { and } 1088 \mathrm{~cm}^{-1} \\
\text { were associated with asymmetric and symmetric phosphodiester } \\
\text { vibrations of nucleic acids. Various glycogen bands were superimposed } \\
\text { between } 1153 \mathrm{~cm}^{-1} \text { and } 1022 \mathrm{~cm}^{-1} \text { while a small peak appearing at } 966 \\
\mathrm{~cm}^{-1} \text { was assigned to C-O phosphodiester moieties }[12,37]\end{array}$ \\
\hline
\end{tabular}


In this investigation the vector normalized second derivatives were analysed to accurately assign and visually maximize differences $[14,29]$ in the spectral regions $\left(850-1800 \mathrm{~cm}^{-1}\right.$ and $2800-3000 \mathrm{~cm}^{-1}$ ) of untreated and treated HeLa cells (Fig. 4).
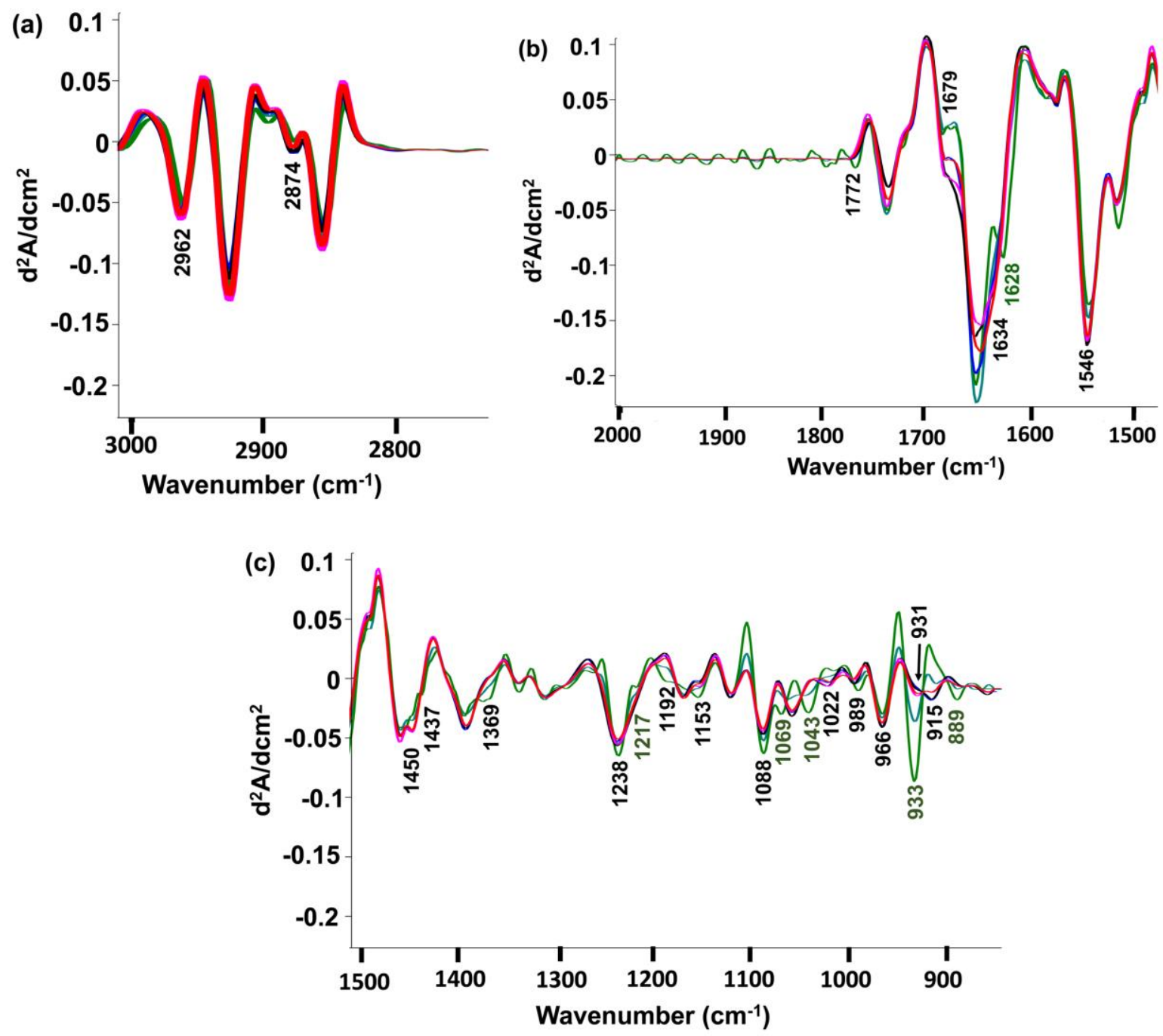

- Untreated $=$ DMSO - Actinomycin D CC 50 Actinomycin D 2xCC - P. ciliatus $\mathrm{CC}_{50}-\mathrm{P}$. ciliatus $2 \mathrm{xCC}_{50}$

Fig. 4. The average second derivative spectra of untreated and treated HeLa cells in the regions of (a) $3000-2800 \mathrm{~cm}^{-1}$ (b) $2000-1500 \mathrm{~cm}^{-1}$ and (c) $1500-850 \mathrm{~cm}^{-1}$. Actinomycin D treated cells had very small variances in most spectral regions. When the cells were treated with the plant extract more severe vibrational band changes occurred as compared to lower concentrations of the plant extract. 


\subsubsection{Significantly altered vibrational bands associated with cellular injury}

All the wavenumbers of the spectra between $850-1800 \mathrm{~cm}^{-1}$ and $2800-3000 \mathrm{~cm}^{-1}$ were evaluated because this is where the treatments under investigation appeared to have had the strongest impact.

\subsubsection{Cytostatic and nontoxic responses}

Nontoxic responses were identified when the cells were treated with DMSO (negative control) and actinomycin D $(0.02 \mu \mathrm{g} / \mathrm{mL})$ using RT-CES. Actinomycin D of higher concentrations $(0.04 \mu \mathrm{g} / \mathrm{mL})$ was defined as inducing a cytostatic response, but none of the vibrational bands was found to be significantly altered. FTIR microspectroscopy was unable to distinguish viable (untreated HeLa cells) from cells treated with DMSO and actinomycin D at $0.02 \mu \mathrm{g} / \mathrm{mL}$ nor could vibrational spectroscopy distinguish healthy from cytostatic cells treated with actinomycin $\mathrm{D}(0.04 \mu \mathrm{g} / \mathrm{mL})$. Cytostatic drugs encourage cells not to proliferate and cause cell cycle arrest. During cytostasis, the cells remain viable with very low energy consumption and thus remain in the cell cycle stage in which the cytostatic drug inhibits further growth. Cells remain morphologically intact with limited expansion and movement. FTIR spectroscopy was able to confirm the data of RT-CES and literature that cytostatic cells on a molecular level were still viable and not committed to death since the cells can still recover. Spectra were similar to untreated / viable cells and / or vehicle treated cells.

\subsubsection{Early stress related responses and cytotoxicity}

P. ciliatus $(9 \mu \mathrm{g} / \mathrm{mL})$ was defined as being non-toxic using RT-CES while significant vibrational band alterations were identified after statistical analysis compared with viable, non-toxic and cytostatic responses. It was postulated that RT-CES could not detect early stress related responses since those responses were based on vibrations of the molecules. Two vibrational bands were identified as significantly altered after the treatment. Those bands were assigned to amide I vibrations $\left(1634 \mathrm{~cm}^{-1}\right.$ and $\left.1679 \mathrm{~cm}^{-1}\right)$. It was found that antiparallel $\beta$-sheets and $\beta$-sheets of amide I could be used to distinguish P. ciliatus $(9 \mu \mathrm{g} / \mathrm{mL}$ and $18 \mu \mathrm{g} / \mathrm{mL}$ ) from nontoxic and cytostatic responses (Table 4). Therefore, $1634 \mathrm{~cm}^{-1}$ and $1679 \mathrm{~cm}^{-1}$ could be used as indicators of early stress related responses that remain evident during cytotoxic responses. The dynamic biochemical reaction towards cytotoxins could, therefore, be seen in the conformational changes in amide I with the increase in $\beta$-sheets and a noteworthy increase in $\alpha$-helices $\left(1655 \mathrm{~cm}^{-1}\right)$. The change in conformation of amide I could 
also be due to different proteins being expressed. Zelig et al. (2009) found that this scenario to be associated with apoptotic cells [29].

Table 4: Significantly (One-way ANOVA post hoc tests: Tukey test, Bonferroni) different bands in the second derivative spectra.

\begin{tabular}{|c|c|c|c|}
\hline $\begin{array}{l}\text { Wavenumber } \\
\left(\mathrm{cm}^{-1}\right)\end{array}$ & $\begin{array}{l}\text { One-way ANOVA p- } \\
\text { value }\end{array}$ & $\begin{array}{l}\text { Multiple comparison } \\
\text { outcomes }\end{array}$ & Assignment \\
\hline 915 & 0.03 & Nontoxic vs. Cytotoxic & $\begin{array}{l}\text { Ribose }- \text { phosphate } \text { main chain } \\
\text { vibrations associated } \\
\text { acids }[38,39]\end{array}$ \\
\hline 931-933 & 0.007 & $\begin{array}{l}\text { Nontoxic vs. Cytotoxic } \\
\text { Cytostatic vs. Cytotoxic }\end{array}$ & $\begin{array}{l}\text { C-O-C ring of deoxyribose in Z-form } \\
\text { DNA }[37,40]\end{array}$ \\
\hline 989 & 0.002 & $\begin{array}{l}\text { Nontoxic vs. Cytotoxic } \\
\text { Cytostatic vs. Cytotoxic }\end{array}$ & $\mathrm{PO}_{3}{ }^{2-}$ vibrations of nucleotides $[41,42]$ \\
\hline 1192 & 0.021 & Nontoxic vs. Cytotoxic & $\begin{array}{l}\text { Deoxyribose - phosphate backbone } \\
\text { with high contribution from the C3' } \\
\text { endo sugar moiety [37] }\end{array}$ \\
\hline 1369 & 0.009 & $\begin{array}{l}\text { Nontoxic vs. Cytotoxic } \\
\text { Cytostatic vs. Cytotoxic }\end{array}$ & $\begin{array}{l}\text { Stretching } \mathrm{C}-\mathrm{N} \text { of cytosine and guanine } \\
\text { [37] }\end{array}$ \\
\hline 1437 & 0 & $\begin{array}{l}\text { Nontoxic vs. Cytotoxic } \\
\text { Cytostatic vs. Cytotoxic }\end{array}$ & $\begin{array}{l}\mathrm{CH}_{2} \text { bending of proteins (amide II) } \\
\text { [43] }\end{array}$ \\
\hline 1450 & 0.012 & Nontoxic vs. Cytotoxic & $\begin{array}{l}\text { Hydrogen bonded Aspartic acids and } \\
\text { Glutamic acid }\left(\mathrm{CH}_{3} \mathrm{COOH}\right)[2] \\
\text { Methylenes of biomolecules [44] }\end{array}$ \\
\hline 1546 & 0.008 & Nontoxic vs. Cytotoxic & Metastable phase of Amide II [45] \\
\hline 1634 & 0.001 & $\begin{array}{l}\text { Nontoxic vs. Cytotoxic } \\
\text { Cytostatic vs. Cytotoxic } \\
\text { PC vs. Cytostatic }\end{array}$ & $\begin{array}{lllll}\begin{array}{l}\text { Antiparallel } \\
{[36,46]}\end{array} & \beta \text {-sheets } & \text { of } & \text { Amide } & \text { I } \\
{[3} & & & \end{array}$ \\
\hline 1679 & 0.006 & $\begin{array}{l}\text { Nontoxic vs. Cytotoxic } \\
\text { Nontoxic vs. PC }\end{array}$ & $\beta$-sheets of Amide I $[2,36]$ \\
\hline 1772 & 0.001 & $\begin{array}{l}\text { Nontoxic vs. Cytotoxic } \\
\text { Cytostatic vs. Cytotoxic } \\
\text { Cytotoxic vs. PC }\end{array}$ & $\begin{array}{lccc}\text { Glycerol bound } & \text { fatty } & \text { acids, } \\
\text { triacylglycerides [47] } & & \end{array}$ \\
\hline 2874 & 0.037 & Nontoxic vs. Cytotoxic & $\begin{array}{l}\mathrm{C}-\mathrm{H} \text { stretching of lipids and proteins of } \\
\mathrm{CH}_{3}[48]\end{array}$ \\
\hline 2962 & 0.016 & Nontoxic vs. Cytotoxic & $\begin{array}{l}\text { C-H stretching of lipids and proteins } \\
\text { [49] }\end{array}$ \\
\hline
\end{tabular}


Other vibrational bands associated with cytotoxicity was also detected in the cells treated with $18 \mu \mathrm{g} / \mathrm{mL}$ (Fig. 4, Table 4). Those bands were associated to nucleic acids $\left(915 \mathrm{~cm}^{-1}\right.$, $\left.933 \mathrm{~cm}^{-1}, 989 \mathrm{~cm}^{-1}, 1192 \mathrm{~cm}^{-1}, 1369 \mathrm{~cm}^{-1}\right)$, proteins $\left(1437 \mathrm{~cm}^{-1}\right.$ and $\left.1546 \mathrm{~cm}^{-1}\right)$, lipids and proteins $\left(1450 \mathrm{~cm}^{-1}, 1772 \mathrm{~cm}^{-1}, 2874 \mathrm{~cm}^{-1}, 2962 \mathrm{~cm}^{-1}\right)$. The $933 \mathrm{~cm}^{-1}$ band was assigned to the vibrational mode of the C-O-C ring of deoxyribose in Z-form DNA [37,38,44]. The region of 1069-1044 $\mathrm{cm}^{-1}$ was assigned to $\mathrm{C}-\mathrm{O}$ vibrations of furanose and is documented to be enhanced in Z-DNA [37]. After the treatment of the cells with P. ciliatus, the peak broke up into two new peaks $\sim 1069$ and $\sim 1043 \mathrm{~cm}^{-1}$. Other bands associated with Z-DNA was also apparent in the same spectra around $1438 \mathrm{~cm}^{-1}$ (shoulder peak not present in the other treated cells) assigned to adenine in Z-DNA, the main Z-DNA marker at $1216 \mathrm{~cm}^{-1}$ as well as the band at $1264 \mathrm{~cm}^{-1}$ assigned to guanine-cytosine helices in Z-form DNA [37]. The $915 \mathrm{~cm}^{-1}$ band became less intense as the treatment increased and the band significantly decreased after $18 \mu \mathrm{g} / \mathrm{mL}$ plant extract treatment. The band was assigned to ribose - phosphate main chain vibrations associated with nucleic acids $[38,39,49-52]$. The transformation of B-DNA to ZDNA can occur under physiological conditions but also due to increased salt concentrations or dehydration of the cells [53]. In this investigation, it is unlikely that the severity of ZDNA formation seen in the cytotoxicity response was only due to dehydration since the control cells showed less severe changes. Lampronti et al. (2006) found that when different plant extracts were incubated with oligonucleotides isolated from cancer cells, an inhibition of transcription factors were evident [54]. Nucleosome formation and placement, as well as the organisation of chromosomes, are affected by the formation of Z-DNA [55], which could have caused the increased absorption of the FTIR peak. Increased salt concentration could be due to additional salts found in the stomata to help with the opening and closing during respiration of the plant. During the day (when the leaves were harvested) the stomata is open which requires high concentration of potassium. Eukaryotic muscle cells have a concentration of $30 \mathrm{mM}$ potassium and a slight increase to $50 \mathrm{mM}$ could induce detectable transformation of B-DNA to Z-DNA [56,57]. Conformational changes in the amide II band could indicate at a glance that biochemical processes involved in chemical stress and cell death induction, such as protein expression related to chemical stress had taken place.

An increase in triacylglycerides and glycerol bound free fatty acids $\left(1772 \mathrm{~cm}^{-1}\right)$ increased during the cytotoxic response. An increase in the absorbance was likely due to increased lipid content within the cells such as the formation of lipid droplets [58]. Lipid droplets formed in T-lymphoblastoid (Jurkat) cells when apoptosis was induced by anthracyclins and other 
cancer drug controls [59]. The reason for the occurrence of the lipid droplets are still not clear, although the degradation of lipids, due to inhibition of the mitochondrial fatty acid $\beta$ oxidation pathway during apoptosis could be a possible reason $[58,60]$. The increase of high wavenumber peaks at $2874 \mathrm{~cm}^{-1}$ and $2962 \mathrm{~cm}^{-1}$ could be indicative of plasma membrane modifications caused by the cytotoxic treatment $[29,61]$.

\subsubsection{Principal component analysis}

The analysis is an unsupervised data reduction method used to identify trends within data based on similarities and differences within the data [62]. Untreated and treated cells at different concentrations of actinomycin D and $P$. ciliatus showed spectral variance which could be described by the first two principal components (PC). The total percentage variance per PC was indicated in brackets (Fig. 5). A total of $59 \%$ of the spectral variance were explained by the data reported. It was seen that PC 1 separated the plant extract treated cells from the untreated and actinomycin D treated cells. FTIR spectra caused clustering of $P$. ciliatus treated cells although the cellular injury was concentration dependent using RT-CES. A possible reason for the clustering could be due to significant alterations of amide I (as found with ANOVA). Clustering of actinomycin D treated cells with untreated cells and DMSO (vehicle) cells confirms that only small spectral changes occurred and it can be assumed that minimal cellular injury was caused by the addition of actinomycin D (0.02 $\mu \mathrm{g} / \mathrm{mL})$. These cells treated with actinomycin D or DMSO were classified as nontoxic. Cells treated with $0.04 \mu \mathrm{g} / \mathrm{mL}$ had a cytostatic RT-CES curve which could not be distinguished from the non-toxic responses using PCA. The cells were reversibly inhibited to proliferate, but still being able to maintain cellular functions for survival. It was postulated that RT-CES could measure the after-effects of cytotoxicity while FTIR could measure the molecular changes using vibrational differences before any morphological effects may become evident. 


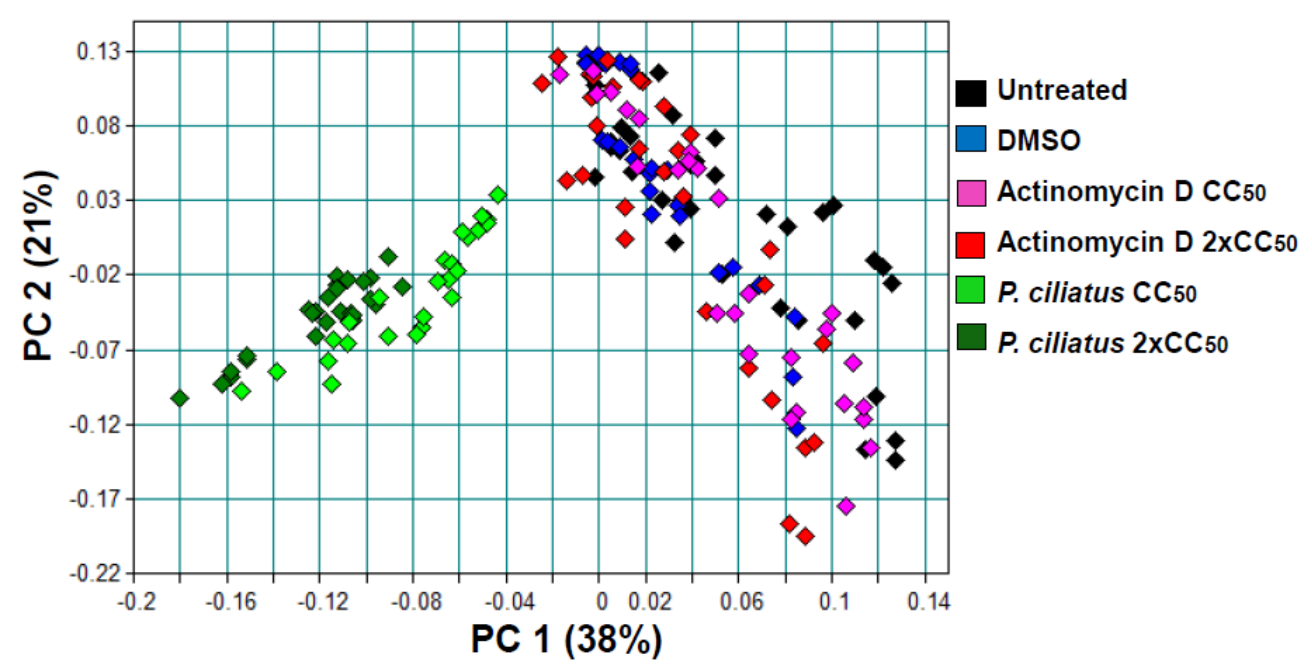

Fig. 5. Principal component analysis of the spectral variance of the treated samples in the regions of 850 $1800 \mathrm{~cm}^{-1}$ and $2800-3000 \mathrm{~cm}^{-1}$.

RT-CES classified cellular injury based on changed morphology of the cells and the ability to attach to the electrodes. Detachment is characteristic of cell death induced by cytotoxins. It was concluded that $18 \mu \mathrm{g} / \mathrm{mL} P$. ciliatus treated HeLa cells induced a cytotoxic response while the other treatments had less severe effects on the cells. RT-CES is an established technique for distinguishing non-toxic, cytostatic and cytotoxic responses which cannot be distinguished by conventional viability assays. FTIR microspectroscopy is widely used to distinguish between different cell types; cell cycle stages as well as cytotoxic treatments. FTIR microspectroscopy confirmed the reversible nature of cytostatic cellular status by detecting that the cells were still viable. Additionally, FTIR detected changes in the molecular vibrations initiated by $9 \mu \mathrm{g} / \mathrm{mL} P$. ciliatus treatment of cells which was associated with the early cellular stress responses.

In conclusion, RT-CES and FTIR microspectroscopy complemented each other by RT-CES detecting morphological changes as indicators of cell injury and could distinguish between viable, cytostatic and cytotoxic responses. FTIR microspectroscopy confirmed that cytostatic cells were not committed to death and could still recover while also describing early cellular stress related responses on a molecular level. Using FTIR microspectroscopy it can be determined whether a treatment were inducing cytostatic responses, early stress related responses or cytotoxic responses. 


\section{Acknowledgements}

The authors would like to acknowledge the following organizations for funding this project; the University of Pretoria, the Technology Innovation Agency (TIA) and the National Research Foundation (NRF) of South Africa.

\section{Conflict of interest statement}

The authors declare no conflict of interest.

\section{References}

[1] R. Sammons, A. Thackray, H. Ledo, P. Marquis, I. Jones, P. Yong, L.E. Macaskie, Characterisation and sintering of nanophase hydroxyapatite synthesised by a species of Serratia, Funct. Mater. Nanotechnologies. 93 (2007) 1-7. doi:10.1088/17426596/93/1/012048.

[2] A. Barth, Infrared spectroscopy of proteins, Biochim. Biophys. Acta. 1767 (2007) 1073-1101. doi:10.1016/j.bbabio.2007.06.004.

[3] P.I. Haris, F. Severcan, FTIR spectroscopic characterization of protein structure in aqueous and non-aqueous media, J. Mol. Catal. B Enzym. 7 (1999) 207-221.

[4] Y. Wang, Q. Zhou, B. Li, B. Liu, G. Wu, M. Ibrahim, G. Xie, Differentiation in MALDI-TOF MS and FTIR spectra between two closely related species Acidovorax oryzae and Acidovorax citrulli, BMC Microbiol. 12 (2012) 182-197. doi:10.1186/1471-2180-12-182.

[5] H.H. Mantsch, L.-P. Choo-Smith, R.A. Shaw, Vibrational spectroscopy and medicine : an alliance in the making, Vib. Spectrosc. 30 (2002) 31-41.

[6] X. Lu, B. Rasco, J. Jabal, D. Aston, M. Lin, M. Konkel, Investigating antibacterial effects of garlic (Allium sativum) concentrate and garlic-derived organosulfur compounds on Campylobacter jejuni by using Fourier Transform infrared spectroscopy, Raman spectroscopy, and electrom microscopy, Appl. Environ. Microbiol. 77 (2011) 5257-5269. doi:10.1128/AEM.02845-10.

[7] W. Petrich, Mid-infrared and Raman spectroscopy for medical diagnostics, Appl. Spectrosc. Rev. 36 (2001) 181-237.

[8] C.M. Krishna, G.D. Sockalingum, R.A. Bhat, L. Venteo, P. Kushtagi, M. Pluot, M. Manfait, FTIR and Raman microspectroscopy of normal , benign , and malignant formalin-fixed ovarian tissues, Anal. Bioanal. Chem. 387 (2007) 1649-1656. doi:10.1007/s00216-006-0827-1. 
[9] M.J. Walsh, M.N. Singh, H.M. Pollock, L.J. Cooper, M.J. German, H.F. Stringfellow, N.J. Fullwood, E. Paraskevaidis, P.L. Martin-Hirsch, F.L. Martin, ATR

microspectroscopy with multivariate analysis segregates grades of exfoliative cervical cytology, Biochem. Biophys. Res. Commun. 352 (2007) 213-219.

doi:10.1016/j.bbrc.2006.11.005.

[10] S. Boydston-White, T. Chernenko, A. Regina, M. Miljkovic, C. Matthaus, M. Diem, Microspectroscopy of single proliferating HeLa cells, Vib. Spectrosc. 38 (2005) 169177. doi:10.1016/j.vibspec.2005.02.028.

[11] K.L. Munro, K.R. Bambery, E.A. Carter, L. Puskar, M.J. Tobin, B.R. Wood, C.T. Dillon, Synchrotron radiation infrared microspectroscopy of arsenic-induced changes to intracellular biomolecules in live leukemia cells, Vib. Spectrosc. 53 (2010) 39-44. doi:10.1016/j.vibspec.2010.02.004.

[12] R. Gasper, J. Dewelle, R. Kiss, T. Mijatovic, E. Goormaghtigh, IR spectroscopy as a new tool for evidencing antitumor drug signatures, Biochim. Biophys. Acta Biomembr. 1788 (2009) 1263-1270. doi:10.1016/j.bbamem.2009.02.016.

[13] A. Derenne, R. Gasper, E. Goormaghtigh, The FTIR spectrum of prostate cancer cells allows the classification of anticancer drugs according to their mode of action, Analyst. 136 (2011) 1134-1141. doi:10.1039/c0an00872a.

[14] S. Machana, N. Weerapreeyakul, S. Barusrux, T. Kanjana, W. Tanthanuch, FTIR microspectroscopy discriminates anticancer action on human leukemic cells by extracts of Pinus kesiya; Cratoxylum formosum ssp. pruniflorum and melphalan, Talanta. 93 (2012) 371-382. doi:10.1016/j.talanta.2012.02.058.

[15] A. Derenne, V. Van Hemelryck, D. Lamoral-Theys, R. Kiss, E. Goormaghtigh, FTIR spectroscopy: A new valuable tool to classify the effects of polyphenolic compounds on cancer cells, Biochim. Biophys. Acta - Mol. Basis Dis. 1832 (2013) 46-56. doi:10.1016/j.bbadis.2012.10.010.

[16] S. Kustermann, F. Boess, A. Buness, M. Schmitz, M. Watzele, T. Weiser, T. Singer, L. Suter, A. Roth, A label-free, impedance-based real time assay to identify drug-induced toxicities and differentiate cytostatic from cytotoxic effects, Toxicol. Vitr. 27 (2013) 1589-1595. doi:10.1016/j.tiv.2012.08.019.

[17] O. Rixe, T. Fojo, Is cell death a critical end point for anticancer therapies or is cytostasis sufficient?, Clin. Cancer Res. 13 (2007) 7280-7287. doi:10.1158/10780432.CCR-07-2141.

[18] E. Urcan, U. Haertel, M. Styllou, R. Hickel, H. Scherthan, F.X. Reichl, Real-time xCELLigence impedance analysis of the cytotoxicity of dental composite components on human gingival fibroblasts, Dent. Mater. 26 (2010) 51-58. doi:10.1016/j.dental.2009.08.007.

[19] P.N. Fonteh, F.K. Keter, D. Meyer, New bis ( thiosemicarbazonate ) gold ( III ) complexes inhibit HIV replication at cytostatic concentrations: Potential for 
incorporation into virostatic cocktails, J. Inorg. Biochem. 105 (2011) 1173-1180. doi:10.1016/j.jinorgbio.2011.05.011.

[20] P. Kapewangolo, A.A. Hussein, D. Meyer, Inhibition of HIV-1 enzymes, antioxidant and anti-inflammatory activities of Plectranthus barbatus, J. Ethnopharmacol. 149 (2013) 184-190. doi:10.1016/j.jep.2013.06.019.

[21] Y.A. Abassi, B. Xi, W. Zhang, P. Ye, S.L. Kirstein, M.R. Gaylord, S.C. Feinstein, X. Wang, X. Xu, Kinetic cell-based morphological screening: prediction of mechanism of compound action and off-target effects, Chem. Biol. 16 (2009) 712-723. doi:10.1016/j.chembiol.2009.05.011.

[22] E. Çetinus, T. Temiz, M. Ergül, A. Altun, Ş. Çetinus, T. Kaya, Thyme essential oil inhibits proliferation of DLD-1 colorectal cancer cells through antioxidant effect, Cumhur. Med. J. 35 (2013) 14-24. doi:10.7197/1305-0028.1757.

[23] S. Diemert, A.M. Dolga, S. Tobaben, J. Grohm, S. Pfeifer, E. Oexler, C. Culmsee, Impedance measurement for real time detection of neuronal cell death, J. Neurosci. Methods. 203 (2012) 69-77. doi:10.1016/j.jneumeth.2011.09.012.

[24] K. Le Roux, L.C. Prinsloo, A.A. Hussein, N. Lall, A micro-Raman spectroscopic investigation of leukemic U-937 cells treated with Crotalaria agatiflora Schweinf and the isolated compound madurensine, Spectrochim. Acta Part A Mol. Biomol. Spectrosc. 95 (2012) 547-554. doi:10.1016/j.saa.2012.04.048.

[25] K. Flower, I. Khalifa, P. Bassan, D. Démoulin, E. Jackson, N. Lockyer, A.T. McGown, P. Miles, L. Vaccari, Synchrotron FTIR analysis of drug treated ovarian A2780 cells: an ability to differentiate cell response to different drugs?, Analyst. 136 (2011) 498507. doi:10.1039/c0an00564a.

[26] T. Gao, Y. Ci, H. Jian, C. An, FTIR investigation of the interaction of tumor cells treated with caffeic acid and chlorogenic acid, Vib. Spectrosc. 24 (2000) 225-231.

[27] C.W. Lukhoba, M.S.J. Simmonds, A.J. Paton, Plectranthus: A review of ethnobotanical uses, J. Ethnopharmacol. 103 (2006) 1-24. doi:10.1016/j.jep.2005.09.011.

[28] P. Kapewangolo, Investigating plant species from the Lamiaceae family for activity against HIV/AIDS and immunomodulatory properties., University of Pretoria, 2013.

[29] U. Zelig, J. Kapelushnik, R. Moreh, S. Mordechai, I. Nathan, Diagnosis of Cell Death by Means of Infrared Spectroscopy, Biophys. J. 97 (2009) 2107-2114. doi:10.1016/j.bpj.2009.07.026.

[30] C. Gaspar-Marques, M.F. Simões, M.L. Valdeira, B. Rodriguez, Terpenoids and phenolics from Plectranthus strigosus, bioactivity screening, Nat. Prod. Res. 22 (2008) 167-177.

[31] M. Abdel-Mogib, H.A. Albar, S.M. Batterjee, Chemistry of the Genus Plectranthus, Molecules. 7 (2002) 271-301. 
[32] S. Huang, R. Zheng, Rosmarinic acid inhibits angiogenesis and its mechanism of action in vitro, Cancer Lett. 239 (2006) 271-280. doi:10.1016/j.canlet.2005.08.025.

[33] S.G. Sawicki, G.C. Godman, On the differential cytotoxicity of actinomycin D, J. Cell Biol. 50 (1971) 746-761.

[34] C.H. Wu, J.S. Pan, W.C. Chang, J.S. Hung, S.J.T. Mao, The molecular mechanism of actinomycin $\mathrm{D}$ in preventing neointimal formation in rat carotid arteries after balloon injury, J. Biomed. Sci. 12 (2005) 503-512. doi:10.1007/s11373-005-6900-5.

[35] C. Matthaus, T. Chernenko, J.A. Newmark, C.M. Warner, M. Diem, Label-free detection of mitochondrial distribution in cells by nonresonant Raman microspectroscopy, Biophys. J. 93 (2007) 668-673. doi:10.1529/biophysj.106.102061.

[36] M. Jackson, H.H. Mantsch, The use and misuse of FTIR spectroscopy in the determination of protein structure, Crit. Rev. Biochem. Mol. Biol. 30 (1995) 95-120. doi:10.3109/10409239509085140.

[37] M. Banyay, M. Sarkar, A. Graslund, A library of IR bands of nucleic acids in solution, Biophys. Chem. 104 (2003) 477-488. doi:10.1016/S0301-4622.

[38] J. Liquier, A. Akhebat, E. Taillandier, Characterization by FTIR spectroscopy of the oligoribonucleotide duplexes r ( A-U )6, and r ( A-U )8, Spectrochim. Acta. 47A (1991) 177-186.

[39] M. Tsuboi, Application of infrared spectroscopy to structure studies of nucleic acids, Applied Spectroscopy Reviews. 3 (1970) 45-90.

[40] M. Ghomi, R. Leterllier, J. Liquier, E. Taillandier, Interpretation of DNA vibrational spetra by normal coordinate analysis, Int. J. Biochem. 22 (1990) 691-699.

[41] M. de la Fuente, A. Hernanz, R. Navarro, IR and Raman study on the interactions of the 5'-GMP and 5'-CMP phosphate groups with $\mathrm{Mg}$ (II), $\mathrm{Ca}$ (II), $\mathrm{Sr}(\mathrm{II}), \mathrm{Ba}$ (II), $\mathrm{Cr}$ (III), $\mathrm{Co}(\mathrm{II}), \mathrm{Cu}(\mathrm{II}), \mathrm{Zn}(\mathrm{II}), \mathrm{Cd}(\mathrm{II}), \mathrm{Al}(\mathrm{III})$ and Ga(III)., J. Biol. Inorg. Chem. 9 (2004) 973986. doi:10.1007/s00775-004-0593-5.

[42] A. Barth, K. Hauser, W. Mantele, J.J.E.T. Corrie, D.R. Trenthams, Photochemical Release of ATP from "Caged ATP" Studied by Time-Resolved Infrared Spectroscopy, J. Am. Chem. Soc. 117 (1995) 10311-10316.

[43] S.-Y. Lin, H.-L. Chu, Fourier transform infrared spectroscopy used to evidence the prevention of $\beta$-sheet formation of amyloid $\beta(1-40)$ peptide by a short amyloid fragment, Int. J. Biol. Macromol. 32 (2003) 173-177. doi:10.1016/S01418130(03)00051-5.

[44] Z. Movasaghi, S. Rehman, D.I. ur Rehman, I. Rehman, Fourier Transform Infrared ( FTIR ) spectroscopy of biological tissues, Appl. Spectrosc. Rev. 43 (2008) 134-179. doi:10.1080/05704920701829043. 
[45] M. Jackson, P.I. Haris, D. Chapman, Fourier Transform Infrared spectroscopic studies of lipids, polypeptides and proteins, J. Mol. Struct. 214 (1989) 329-355.

[46] S.-Y. Lin, H.-L. Chu, Y.-S. Wei, Pressure-induced transformation of alpha-helix to beta-sheet in the secondary structures of amyloid beta (1-40) peptide exacerbated by temperature, J. Biomol. Struct. Dyn. 19 (2002) 619-625. doi:10.1080/07391102.2002.10506768.

[47] E. Gazi, P. Gardner, N.P. Lockyer, C. a Hart, M.D. Brown, N.W. Clarke, Direct evidence of lipid translocation between adipocytes and prostate cancer cells with imaging FTIR microspectroscopy, J. Lipid Res. 48 (2007) 1846-56. doi:10.1194/jlr.M700131-JLR200.

[48] L.M. Miller, P. Dumas, From structure to cellular mechanism with infrared microspectroscopy, Curr. Opin. Struct. Biol. 20 (n.d.) 649-656. doi:10.1016/j.sbi.2010.07.007.

[49] J. Cao, E.S. Ng, D. McNaughton, E.G. Stanley, A.G. Elefanty, M.J. Tobin, P. Heraud, The characterisation of pluripotent and multipotent stem cells using Fourier transform infrared microspectroscopy, Int. J. Mol. Sci. 14 (2013) 17453-17476. doi:10.3390/ijms140917453.

[50] D. Ami, P. Mereghetti, A. Natalello, S.M. Doglia, Fourier Transform Infrared microspectroscopy as a tool for embryonic stem cell studies, methodological advances in the culture, manupulation and utalization of embryonic stem cells for basic and practical applications, InTech, 2011.

[51] E. Benedetti, E. Bramanti, F. Papineschi, I. Rossi, E. Benedetti, Determination of the relative amount of nucleic acids and proteins in leukemic and normal lymphocytes by means of Fourier Transform Infrared Microspectroscopy, Appl. Spectrosc. 51 (1997) 792-797.

[52] B.R. Wood, B. Tait, D. McNaughton, Fourier Transform Infrared Spectroscopy as a Method for Monitoring the Molecular Dynamics of Lymphocyte Activation, Appl. Spectrosc. 54 (2000) 353-359.

[53] M. Filimonova, V. Gubskaya, R. Davidov, A. Garusov, I. Nuretdinov, Metal binding induces conversion of B- to the hybrid B-Z-form in natural DNA, Int. J. Biol. Macromol. 43 (2008) 289-294. doi:10.1016/j.ijbiomac.2008.06.010.

[54] I. Lampronti, M.T. Hassan Khan, N. Bianchi, G. Feriotto, C. Mischiati, M. Borgatti, R. Gambari, Effects of medicinal plant extracts on molecular interactions between DNA and transcription factors, Adv. Phytomedicine. 2 (2006) 35-43. doi:10.1016/S1572557X(05)02003-9.

[55] M.M. Garner, G. Felsenfeld, Effect of Z-DNA on nucleosome placement, J. Mol. Biol. 196 (1987) 581-590. 
[56] F. Azorin, A. Nordheim, A. Rich, Formation of Z-DNA in negatively supercoiled plasmids is sensitive to small changes in salt concentration within the physiological range, EMBO J. 2 (1983) 649-655.

[57] E.A.C. MacRobbie, Ionic relations of guard cells, in E. Zeiger, G.D. Farquha, I.R. Cowan (Eds.), Stomatal Funct., Stanford University Press, California, 1987: pp. 125162.

[58] N. Zaidi, L. Lupien, N.B. Kuemmerle, W.B. Kinlaw, J. V Swinnen, K. Smans, Lipogenesis and lipolysis: the pathways exploited by the cancer cells to acquire fatty acids, Prog. Lipid Res. 52 (2013) 585-589. doi:10.1016/j.plipres.2013.08.005.

[59] M. Di Vito, L. Lenti, A. Knijn, E. Iorio, F. D’Agostino, A. Molinari, A. Calcabrini, A. Stringaro, S. Meschini, G. Arancia, A. Bozzi, R. Strom, Podo, F, 1H NMR-visible mobile lipid domains correlate with cytoplasmic lipid bodies in apoptotic Tlymphoblastoid cells, Biochim. Biophys. Acta. 1530 (2001) 47-66.

[60] G. Birarda, D. Bedolla, E. Mitri, S. Pacor, G. Grenci, L. Vaccari, Apoptotic pathways of U937 leukemic monocytes investigated by infrared microspectroscopy and flow cytometry, Analyst. In press (2014). doi:10.1039/C4AN00317A.

[61] G.E. Jamin, L. Miller, J. Moncuit, W. Fridman, P. Dumas, J. Teillaud, Chemical heterogeneity in cell death: Combined synchrotron IR and fluorescence microscopy studies of single apoptotic and necrotic cells, Biopolym. 72 (2003) 366-373.

[62] D.I. Ellis, R. Goodacre, Metabolic fingerprinting in disease diagnosis : biomedical applications of infrared and Raman spectroscopy, Analyst. 131 (2006) 875-885. doi:10.1039/b602376m. 